\title{
Expression of TNF and TNF Receptors (p55 and p75) in the Rat Brain after Focal Cerebral Ischemia
}

\author{
Galina I. Botchkina,* Malcolm E. Meistrell III,* \\ Inna L. Botchkina,* and Kevin J. Tracey*,t \\ *The Picower Institute for Medical Research, Manhasset, \\ New York, U.S.A. \\ ${ }^{\dagger}$ Department of Surgery, North Shore University Hospital, Manhasset, \\ New York, U.S.A.
}

\begin{abstract}
Cerebral ischemia induces a rapid and dramatic up-regulation of tumor necrosis factor (TNF) protein and mRNA, but the cellular sources of TNF in the ischemic brain have not been defined. The diverse activities of TNF are mediated via ligand interaction with two distinct receptors, p55 and p75, which activate separate intracellular signal transduction pathways, leading to distinct biological effects. Since the effects of cerebral ischemia on TNF receptor (TNFR) expression are unknown, we examined the cellular localization and protein expression of TNF and its two receptors in the rat cerebral cortex in response to permanent middle cerebral artery (MCA) occlusion. The results indicate that focal cerebral ischemia up-regulates expression of TNF and both TNFRs within the ischemic cortex. The most abundant type of
\end{abstract}

TNF immunoreactivity (IR) was a punctate and filamentous pattern of transected cellular processes; however, cell bodies of neurons, astrocytes, and microglia, as well as infiltrating polymorphonuclear (PMN) leukocytes also showed TNF IR. Brain vasculature displayed TNF IR not only within endothelial cells but also in the perivascular space. MCA occlusion induced significant up-regulation of TNF receptors, with p55 IR appearing within $6 \mathrm{hr}$, significantly before the appearance of p75 IR at $24 \mathrm{hr}$ after the onset of ischemia. Since p 55 has been implicated in transducing cytotoxic signalling of TNF, these results support the proposed injurious role of excessive TNF produced during the acute response to cerebral ischemia.

\section{INTRODUCTION}

Tumor necrosis factor (TNF), a pleiotropic cytokine produced during the physiological response to infection, injury, or ischemia, has been implicated in disease pathophysiologies of the central nervous system (CNS) such as cerebral meningitis, cerebral malaria, multiple sclerosis, Alzheimer's disease, HIV encephalopathy, and cerebral ischemia. A large body of evidence suggests that the relative overproduction of TNF during cerebral ischemia amplifies and extends the severity of cell death during brain ischemia. The expression of TNF protein and mRNA are stimulated

Address correspondence and reprint requests to: Dr. Galina I. Botchkina, The Picower Institute for Medical Research, 350 Community Drive, Manhasset, NY 11030, U.S.A. Phone: 516-562-9574; Fax: 516-365-5090. during cerebral ischemia, with peak protein expression occurring by $6 \mathrm{hr}$ after the onset of ischemia (1), or shortly thereafter (2). In animal models of head injury, TNF synthesis is also increased, possibly secondarily to the onset of cerebral ischemia (3-6). Cerebral hypoxia-ischemia increased TNF mRNA in perinatal rat brain (7), and an early and marked increase of TNF in neuronal somata has been observed following surgical injury (5).

As in other biological conditions in which low levels of TNF can be beneficial, but higher levels are injurious (8), excessive intracerebral TNF in the context of cerebral ischemia is damaging. Therapeutic implications are suggested by the attenuation of brain-damaging ischemic sequelae following administration of anti-TNF antibodies or receptor constructs. Repeated 
intracerebroventricular administration (9), or intracortical injection of anti-TNF antibodies (10) significantly limited the volume of ischemic brain damage. The administration of soluble type 1 TNF receptors (TNFRs) significantly protected against the development of brain infarction in SHR rats (11). Topical application of a dimeric polyethylene glycol-linked TNFRl also significantly protected against focal cerebral infarction in $\mathrm{BALB} / \mathrm{c}$ mice (12). Evidence for a protective role of TNF in cerebral ischemia was observed in genetically engineered knock-out mice rendered devoid of TNF receptors, which develop significantly larger cerebral infarctions than wild-type controls (13). Considered together, these results indicate that in response to ischemia, low levels of TNF may be beneficial, but excessive production of the cytokine is deleterious.

TNF can be produced by many cells, including lymphocytes, natural killer cells, endothelial cells, mast cells, smooth muscle cells, etc. $(14,15)$. In the CNS, microglia $(16,17)$, astrocytes (18-20) and choroid plexus ependymal cells (21) have each been shown to produce TNF in vitro. The pleiotropic activities of TNF are mediated via ligand interaction with two distinct TNF receptors termed TNFR1, or p55, and TNFR2, or p75, that are independently expressed on a variety of cells including neurons and glial cells (reviewed in refs. 22-26). Each receptor can be cleaved into a soluble form that is capable of binding and neutralizing TNF. Cell expression of the TNF receptors is closely regulated in response to ischemia and injury, providing an important level of control over the biological activities of TNF. Moreover, the cellular responses to TNF are determined differently by these two receptor populations as they activate separate intracellular signal transduction pathways that modulate distinct cellular responses. For instance, the p55 receptor mediates TNF-induced apoptotic cell death (reviewed in ref. 27), but the function of p75 is more obscure. It has been implicated in cell proliferation and protection against death $(28,29)$, although it is capable of transducing apoptotic signals in certain cell lines (30). Tada et al. (31) recently found that p55 mRNA was weakly expressed in normal brain. Inhibition of p75 by antisense oligonucleotides significantly increased TNF-, hypoxia- and beta amyloidmediated neuronal cell death (32), suggesting that p75 TNFR may participate in protective responses following insult or injury.

Despite the importance of TNF in the mediation of cerebral ischemia, cellular sources of
TNF and the expression of TNF receptors are incompletely characterized. Accordingly, we examined here the expression and cellular localization of TNF and two TNF receptors in the cerebral cortex after permanent MCA occlusion. Our results indicate that TNF is expressed in ischemic neurons, astrocytes, microglia, endothelial cells, and in infiltrating polymorphonuclear leukocytes. Moreover, the onset of cerebral ischemia enhanced the expression of both the $\mathrm{p} 55$ and the p75 TNF receptors, suggesting that cytotoxic activities of TNF might be mediated through both increased synthesis of the cytokine and up-regulated expression of one or both receptors.

\section{MATERIALS AND METHODS}

\section{Surgery}

Permanent focal cerebral ischemia was performed as described elsewhere $(33,34)$. Briefly, male Lewis rats were anesthetized with ketamine and both common carotid arteries were exposed and ligated. The entire temporalis muscle was removed and the bone adjacent to the zygomatic arch was drilled to open the surface of the brain. The middle cerebral artery was permanently occluded by electrocoagulation. After that, the contralateral common carotid artery (CCA) was occluded for $\mathrm{l} \mathrm{hr}$ while the ipsilateral one was permanently ligated. Temperature was maintained at about $37^{\circ} \mathrm{C}$. After $\mathrm{l} \mathrm{hr}$, the temporary occlusion of the CCA was removed and the neck and head incisions were closed. The animal was then allowed free access to food and water.

\section{Tissue Preparation}

At different times (2-24 hr) after the onset of MCA occlusion, animals were deeply anesthetized and perfused as described by Breder et al. (35). Briefly, $30 \mathrm{ml}$ of saline ( $\mathrm{pH} 7.4)$ was perfused transcardially followed by $100 \mathrm{ml}$ of $4 \%$ formaldehyde in phosphate-buffered saline (PBS) $(\mathrm{pH} 6.5)$ and $100 \mathrm{ml}$ of the same fixative at $\mathrm{pH}$ 8.5. Animals were allowed to postfix for $30 \mathrm{~min}$, then perfused with $50 \mathrm{ml}$ of $20 \%$ sucrose solution in $0.1 \mathrm{M}$ PBS (pH 7.4). Tissues of interest were removed and kept in sucrose solution overnight at $4^{\circ} \mathrm{C}$. Sections (10 $\mu \mathrm{m}$ thick) were cut on a cryostat and airdried for $1 \mathrm{hr}$. Adjacent sections were used for immunocytochemical and histological staining.

To study TNF receptor expression, fresh frozen brain sections were fixed in absolute methanol at $-20^{\circ} \mathrm{C}$. 


\section{Immunocytochemistry}

Sections were incubated in a solution containing $0.3 \% \mathrm{H}_{2} \mathrm{O}_{2}$ and $0.3 \%$ Triton $\mathrm{X}-100$ in $0.01 \mathrm{M}$ PBS for $10 \mathrm{~min}$ at room temperature. Washed sections were then incubated in a blocking solution containing $1 \%$ BSA, 5\% normal goat serum, and $0.3 \%$ Triton X-100 in $0.01 \mathrm{M}$ PBS for $1 \mathrm{hr}$ at room temperature (RT) and then incubated for $24 \mathrm{hr}$ at $4^{\circ} \mathrm{C}$ with a 1:100 dilution of the monoclonal hamster anti-murine TNF or monoclonal hamster anti-mouse TNF receptor (p55 or p75) antibodies (Genzyme) with $0.3 \%$ Triton X-100 and $0.1 \%$ BSA and 3\% normal serum in $0.01 \mathrm{M}$ PBS. Washed sections were incubated for 1-2 hr RT in $0.5 \%$ biotinilated anti-hamster IgG (Vector Labs) or biotinilated anti-Armenian hamster IgG (Jackson Immunoresearch Lab) for 1-2 hr. The reaction product was vizualized with $0.01 \%$ hydrogen peroxide and $0.05 \%$ diaminobenzidine (DAB) as a chromogen. Sections were then processed for light microscopy by standard methods.

For detection of possible colocalization of TNF and TNFR immunoreactivity (IR) with particular cell types, double-label immunofluorescence was used. After incubation in a blocking solution, brain sections were incubated in a mixture of the diluted primary antibodies: hamster anti-TNF, or anti-p55 or anti-p75 with rabbit anti-glial fibrillary acidic protein (GFAP) (DAKO) or rabbit anti-neurofilament 200 (NF200). As secondary antibodies, a mixture of a rhodamineconjugated goat anti-hamster IgG and fluorescein-conjugated goat anti-rabbit IgG (Vector Lab) was used. After $2 \mathrm{hr}$ of incubation with the secondary antibodies, the sections were processed for microscopic analysis with epifluorescence according to standard processes. Specificity was determined by incubation of tissue without primary antibodies or by preabsorption of antiTNF antibodies with recombinant mouse TNF (Genzyme).

\section{TUNEL Staining}

We used a terminal deoxynucleotidyltransferase (TdT)-mediated dUTP-biotin nick end-labeling (TUNEL) method (ApopTag kit, Oncor) for specific staining of DNA fragmentation in apoptotic cells. Ten micrometer-thick brain sections obtained as described above were post-fixed in ethanol-acetic acid $(2: 1)$ for $5 \mathrm{~min}$ at $-20^{\circ} \mathrm{C}$ and washed with $0.01 \mathrm{M}$ PBS three times for $5 \mathrm{~min}$. After digesting protein in tissue sections using proteinase $\mathrm{K}(20 \mu \mathrm{g} / \mathrm{ml})$ for $15 \mathrm{~min}$ at room temperature, and quenching endogenous peroxidase activity with $1 \% \mathrm{H}_{2} \mathrm{O}_{2}$ in PBS for $5 \mathrm{~min}$ at room temperature, slides were placed in equilibration buffer and then incubated with workingstrength TdT enzyme for $1 \mathrm{hr}$ at $37^{\circ} \mathrm{C}$. After 10 min of incubation in stop/wash buffer and washing in PBS, sections were incubated for $30 \mathrm{~min}$ with anti-digoxigenin-peroxidase, washed again, and reacted with diaminobenzidine. As a negative control, we used section incubated with a reaction buffer and distilled water instead of TdT enzyme. Double immunofluorescent labeling was performed on the same brain sections after the visualization of TUNEL-positive cells.

\section{RESULTS}

\section{Neuronal and Glial Expression of TNF}

Focal cerebral ischemia involving permanent MCA occlusion induced the widespread appearance of TNF-like immunoreactivity (IR) within the ischemic core as well as the surrounding hypoperfused penumbra within $6 \mathrm{hr}$ after the onset of ischemia (Fig. 1A, B). The absolute number of TNF-positive cells per unit area was significantly higher within the penumbra than in the ischemic core, principally attributable to greater cell death within the volume of the most severely compromised blood flow. Minimal or nondetectable TNF IR was observed at $2 \mathrm{hr}$ after the onset of ischemia within the developing infarct. Early after ischemia, the contralateral cortex showed no TNF IR (Fig. 1C), but at $24 \mathrm{hr}$ after the onset of ischemia, some microglial cells in the contralateral cortex exhibited a very low level of TNF IR. No specific staining was seen in brain sections that were incubated without primary antibodies or when diluted anti-TNF antibodies were preadsorbed with recombinant mouse TNF. Generally, TNF IR was punctate and sometimes a filament-like pattern with swollen varicosities (Fig. 1E) was seen; patterns are typical of a protein distributed in neural processes. Neuronal and glial cell bodies also expressed moderate TNF IR. Many of TNF-expressing neurons were in close proximity to activated microglial cells (Fig. 1D), which exhibited a high level of TNF IR. By $24 \mathrm{hr}$ after the onset of ischemia, two distinct morphologic types of TNF expressing microglial cells were present: active microglia with a few long, thick processes (Fig. 1D), and transformed, reactive, macrophage-like cells with large cell bodies and very short or no processes (Fig. 1H). 

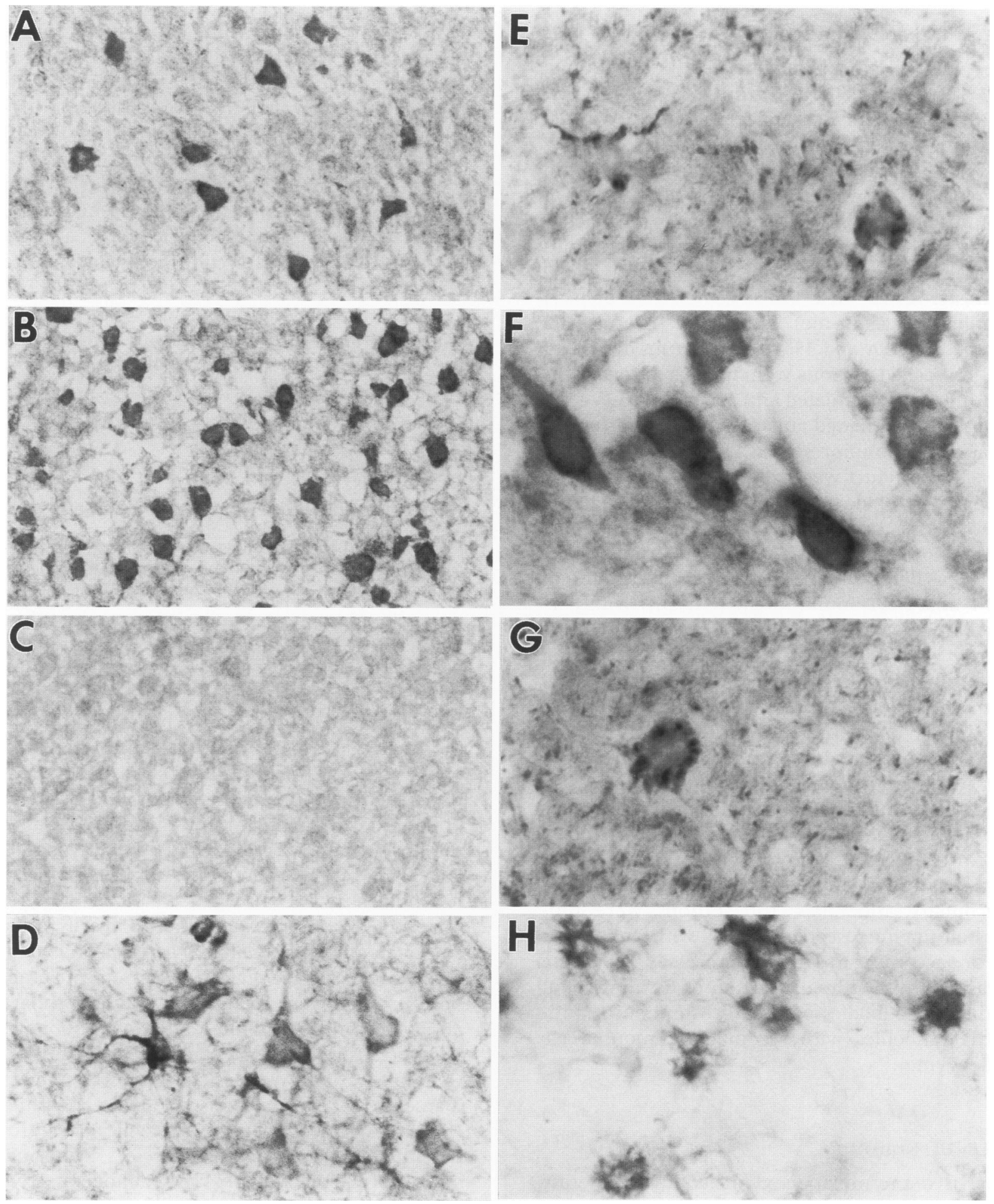

FIG. 1. TNF immunoreactivity after focal cerebral ischemia

The appearance of TNF immunoreactivity (TNF IR) within the densely ischemic core (A), and adjacent hypoperfused penumbra (B) at $6 \mathrm{hr}$ after permanent MCA occlusion; the contralateral side revealed a virtual lack of TNF IR (C). High-magnification photomicrographs (D-H) illustrate a qualitatively different appearance of cell-associated TNF IR. The most abundant type, punctate and filamentous, was observed 6-24 hr after the onset of ischemia (E). Cytoplasmic expression of TNF IR also occurred (F). TNF IR reaction product at the cell surface presumably reflects membrane-associated 26-kD TNF (G). TNF expression was visualized within activated microglial cells adjacent to TNF-positive neurons (D) and within transformed, macrophage-like microglia (H). 

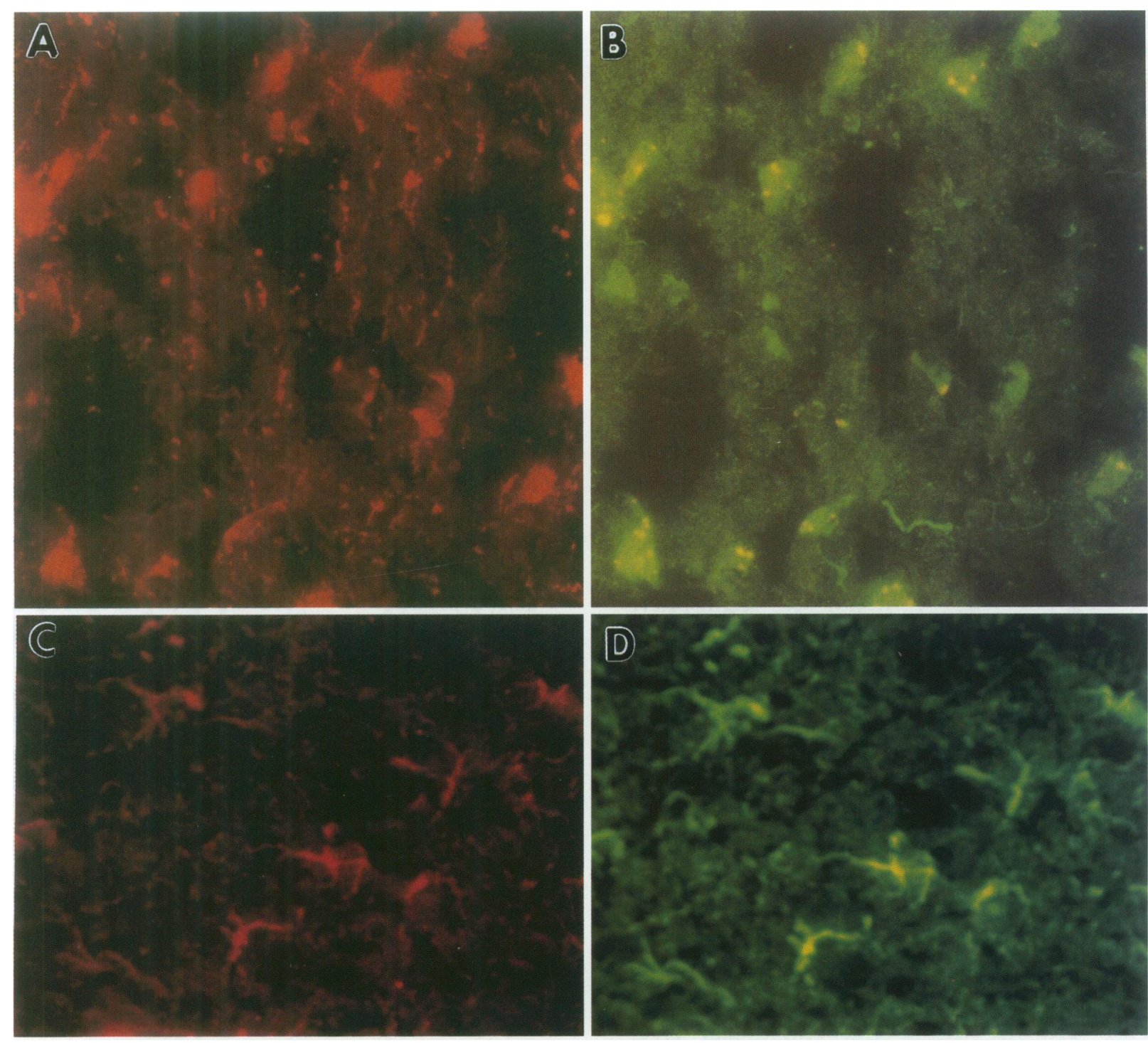

FIG. 2. Double-fluorescent immunohistochemistry showing the colocalization of TNF IR with neuronal (NF200) and glial (GFAP) cell markers

The majority of cells expressing TNF within the ischemic cortex (A, red filter) also showed NF200 IR (B, green filter). However, the dense network of TNF-positive fibers showed a negative correlation with this neuronal marker, suggesting that they represent glial processes. GFAP-positive astrocytes within the hypoperfused penumbra (D, green filter) also show TNF IR (C, red filter).

In addition, some cells clearly demonstrated punctate TNF IR at the cell margin (Fig. 1G), probably reflecting membrane-associated TNF.

Double-label fluorescence immunocytochemistry showed that virtually all neurons in the ischemic core and a majority of those in the adjacent penumbra were TNF immunoreactive (Fig. 2A, B). Separate exposures of the same field show the colocalization of TNF (red filter) and the neuronal marker NF200 (green filter) IR within the ischemic core. In addition to the co- localization of NF200 IR and TNF IR in neuronal cell bodies, a dense network of TNF-positive filaments (Fig. 2A) that are not NF200 immunoreactive (Fig. $2 \mathrm{~B}$ ), are also readily visible; presumably these represent glial processes. In the ischemic penumbra, most hypertrophic astrocytes expressed both GFAP IR and TNF IR (Fig. 2C, D; TNF IR, red filter and GFAP IR, green filter). It is noteworthy that almost no astrocytic cell bodies were observed within the ischemic core. The above described distribution of TNF IR 
was not significantly different at $24 \mathrm{hr}$, although the volume of severely damaged brain tissue (ischemic core) was larger and had taken on a more spongiform appearance that demonstrated fewer intact cell profiles. At $24 \mathrm{hr}$, the density of TNF IR within cell bodies in the ischemic penumbra was slightly lower than at $6 \mathrm{hr}$ after MCA occlusion, but the appearance of punctate and filamentous TNF IR within penumbra was more prominent.

Dense TNF IR was detected near the surface of the ischemic brain (Fig. 3A; 4A, B). Doubleimmunostaining revealed the colocalization of TNF IR and GFAP IR within the outermost part of the cortex (Fig. 3A, B). High-resolution photomicrographs clearly show that distinct cellular elements contribute to the TNF IR in this area, i.e., microglia (Fig. 4A) and astrocyte end-feet (Fig. 4B). This distribution of TNF IR was not detected in the contralateral hemisphere (Fig. 4C). MCA occlusion induced the appearance of perivascular TNF IR in the subarachnoid space (arrow on Fig. 3A) and on the surface of brain capillaries within the ischemic cortex (Figs. 3C and 5A). CNS capillaries, in contrast to large brain vessels, are almost completely surrounded by astrocytic endfeet (Fig. 3D). Just outside the immediate perivascular zone of the small cortical vessels, GFAP IR was co-extensive with TNF IR (Fig. 3C, D). The TNF IR on larger brain vessels within the subarachnoid space, however, did not colocalize with GFAP IR (Fig. 3A, B, arrows). Transected brain vessels also revealed dense TNF IR within the endothelial layer (Fig. 5B); no staining was observed in negative control tissues incubated with the absence of TNF antibodies (Fig. 5C).

\section{Inflammatory Cell Expression of TNF}

Focal brain ischemia induced prominent PMN infiltration ipsilateral to the infarction. Most infiltrating PMNs detected $24 \mathrm{hr}$ after the onset of ischemia were located in the subarachnoid space. They were also identified within the ischemic core (Fig. 6A). All such marginated PMNs expressed diffuse cytoplasmic TNF IR with more dense punctate TNF IR at the cell surface (Fig. 6C). In addition, choroid plexus cells in the lateral ventricle ipsilateral to the MCA occlusion expressed a low to moderate degree of cytoplasmic TNF IR.

\section{Expression of TNF Receptors}

In normal brain, and within cortex contralateral to the infarction, p55 IR appeared as rare, irregular islets of lightly immunoreactive fibers of different lengths and thicknesses. At 4-6 hr after permanent MCA occlusion, a dramatic increase of immunoreactive $\mathrm{p} 55$ protein expression was observed within the ipsilateral ischemic cortex, resulting in a significantly larger (5- to 10 -fold) number of p55-positive patches exhibiting much more dense filamentous immunoreactivity (Fig. 7A, B) within a more continuous network of fine filamentous and punctate p55 IR (Fig. 7C). Neuronal cell bodies within the ischemic cortex also expressed low to moderate p55 immunoreactivity at this timepoint. The level of protein expression and the number of p55 immunoreactive cells increased further $24 \mathrm{hr}$ after the onset of ischemia (Fig. 7D). The immunoreactive product was predominantly localized at the cell surface, rather than within the cytoplasm.

The above described "patchy" distribution of p55 immunoreactivity was not observed in p75 immunocytochemistry; no p75 IR was observed in samples taken at $6 \mathrm{hr}$ after MCA occlusion. By $24 \mathrm{hr}$, however, many neurons within the ischemic core and within the proximal penumbral zone expressed low to moderate levels of p75 IR (Fig. 7F); no such p75-positive profiles were detected in the contralateral cortex (Fig. 7E). In addition to cell-associated p75 IR, the ipsilateral cortex in the zone of greatest ischemia also expressed punctate $D A B$ reaction product localized at or near the cell surface (Fig. 7G, H). MCA occlusion also induced the appearance of dense, specific p55 and p75 IR at the inner surface of transacted brain vessels (Fig. 8). In contrast to TNF expression in brain vessels (see Fig. 5B), p55 and p75 immunoreactive products appear to localize at the endothelial cell surface rather than in the cytoplasm (Fig. 8A, B). Immunocytochemical analysis of brain vasculature in control (no stroke) animals did not show TNF receptor protein-associated immunoreactivity (Fig. 8C).

In double immunofluorescent-stained material from the core and penumbra sampled at 24 hr after the onset of ischemia, both TNF receptors colocalized with NF200 IR. No correlation of immunoreactive $\mathrm{p} 55$ or $\mathrm{p} 75$ proteins with GFAP IR was detected in association with hypertrophic astrocytic cell bodies in the ischemic penumbra, nor was it found within the ischemic core. p55 and p75 immunoreactivity was associated with 

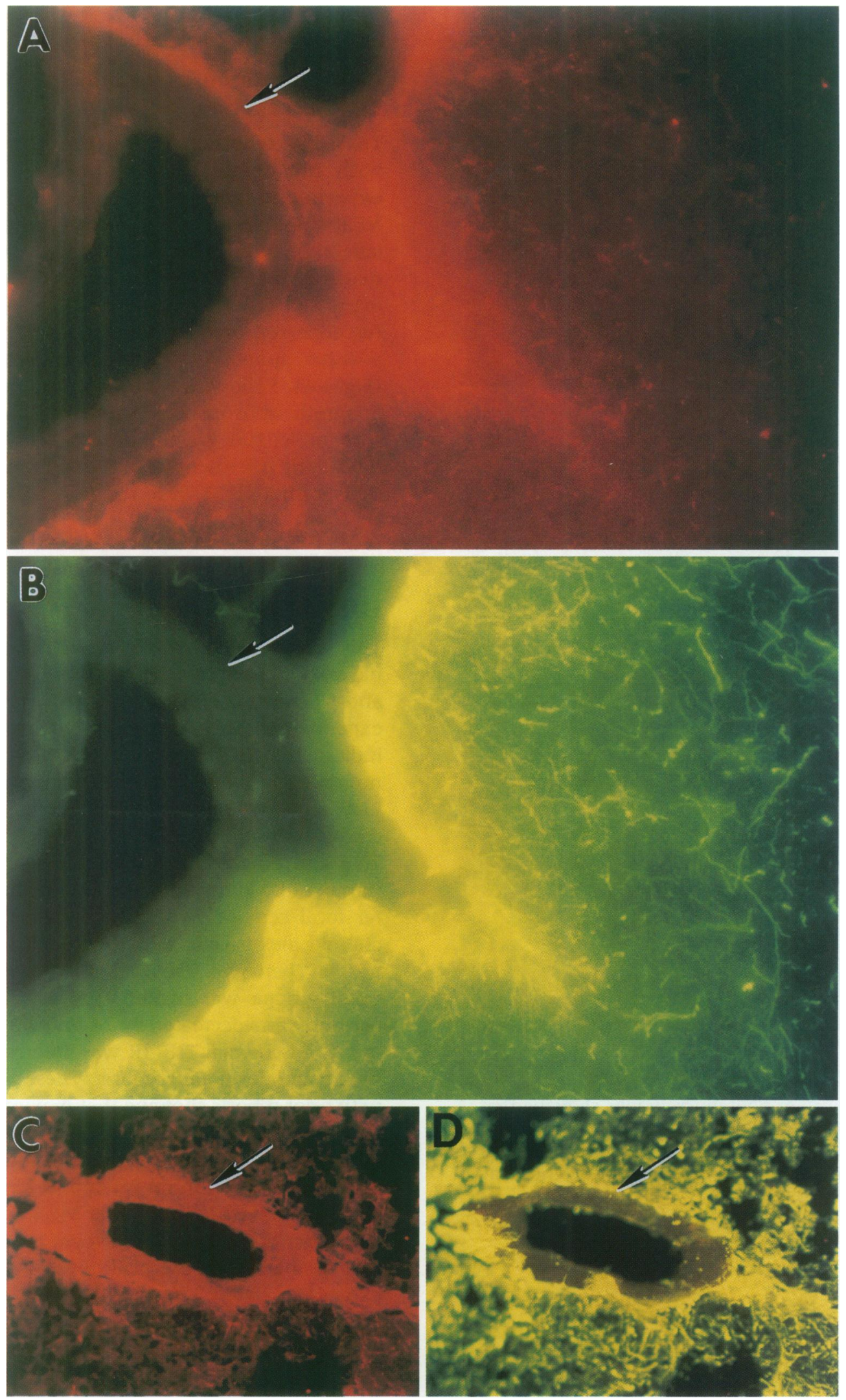

FIG. 3. Double-immunofluorescence for TNF and GFAP in the ischemic cortex

Double immunofluorescence for TNF (A, C; red filter) and GFAP (B, D; green filter) shows the colocalization of TNF and GFAP at the brain surface (A, B) and surrounding brain capillaries (C, D); in each case, the zone comprises astrocytic end-feet. No such colocalization was observed on the larger, noncapillary brain vessels (arrows on A, B), which also do not have an enveloping layer of astrocytic processes. Note colocalization of TNF and GFAP IR on small capillaries (arrows on C, D). 


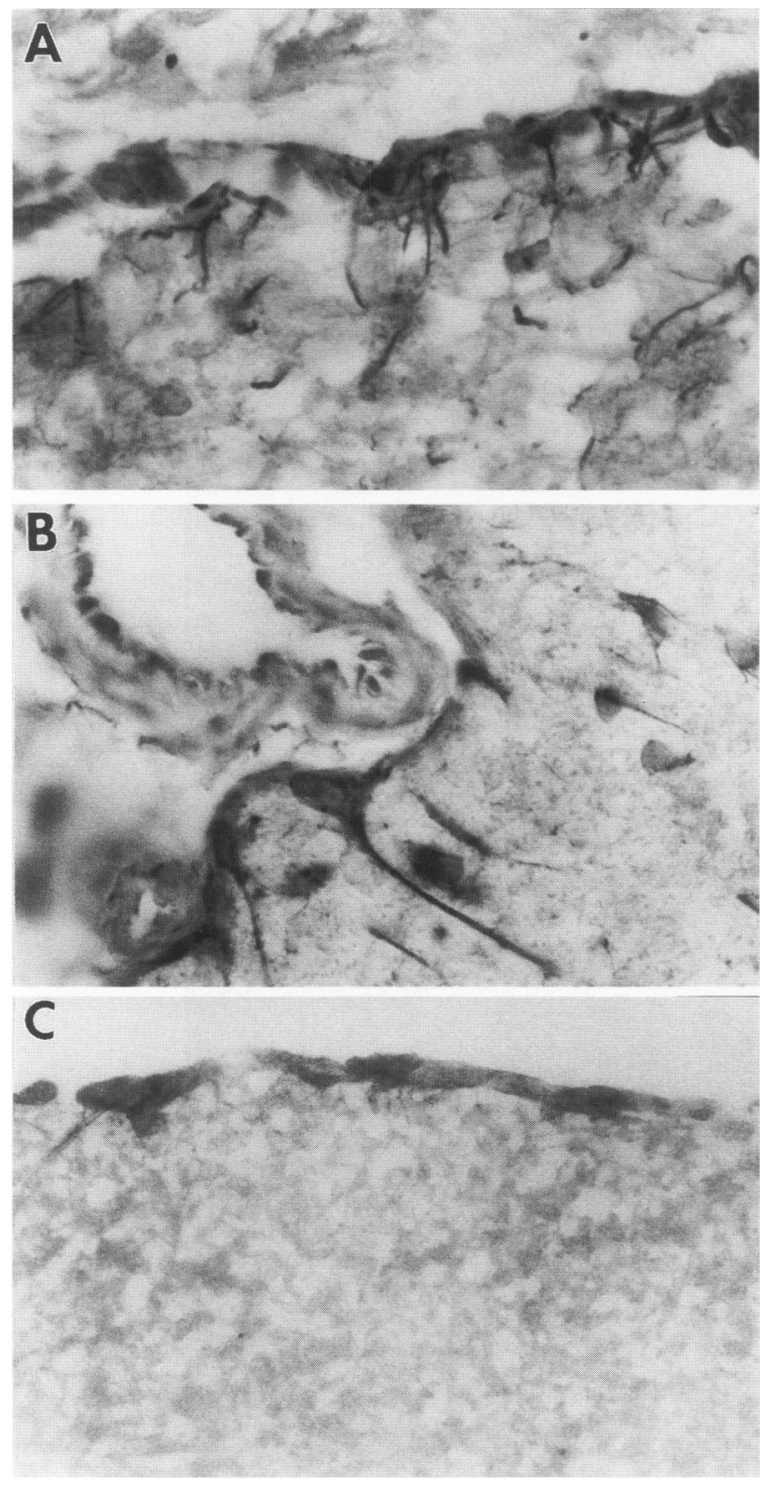

FIG. 4. TNF IR at the brain surface

High magnification photomicrographs showing that TNF IR was apparently contributed by microglia (A) and astrocyte end-feet (B) at the ischemic brain surface; no such TNF IR was detected on the contralateral side $(C)$.

GFAP IR, but not with NF200 IR, at the cortical surface, in association with brain capillary walls, and on the ventricular surface. Non capillary brain vessels also expressed p55 and p75 IR at their parenchymal surface, but there was no GFAP-positive staining associated with these larger vessels.

\section{Colocalization of Neuronal TNF IR with TUNEL Labeling}

To study whether TNF expression correlates with cell death, we performed an additional experiment with triple staining (TNF and NF200 double-immunofluorescence plus TUNEL labeling). Within ischemic cortex, only those neurons that exhibited apoptotic changes also expressed TNF IR (Fig. 9). Cells with green fluorescence represented normal neurons; TUNELpositive apoptotic neurons had brown nuclei (Fig. 9A). Yellowish staining of the cytoplasm of apoptotic neurons was a result of double exposure of NF200 green fluorescence and brightfield light microscopy for TUNEL-positive cells. Cells with TNF IR were red (Fig. 9B).

\section{DISCUSSION}

This study presents the first evidence that multiple cell types express TNF and TNF receptors (p55 and p75) in ischemic brain cortex in response to experimental MCA occlusion. Our results further indicate that TNF expression in cerebral ischemia is not an exclusive feature of the neuronal cell population. Using morphological criteria, as well as double immunolabeling with antibodies against TNF and different cell markers, we identified a number of additional cell types expressing TNF after focal cerebral ischemia: astrocytes, microglia, choroid plexus cells, endothelial cells, PMNs, and possibly, pericytes. The level of TNF IR within neuronal somata was maximal by $6 \mathrm{hr}$ after MCA occlusion and decreased by $24 \mathrm{hr}$. At $2 \mathrm{hr}$ after the onset of ischemia, TNF IR was absent or minimal within the developing infarct. These results agree with prior reports showing that maximal TNF protein expression occurred at 8-18 hr after brain lesioning (3), and with the observation that TNF mRNA expression in rat cerebral cortex was maximal between 6 and $12 \mathrm{hr}$ after MCA occlusion (2). An earlier time course was shown by Buttini et al. (1), during which the peak level of TNF mRNA expression was at $3 \mathrm{hr}$ after the onset of ischemia.

In addition to neurons, several types of activated microglial cells express TNF IR in association with focal cerebral ischemia. Transient ischemia (36-38), and soma-induced seizures (39) produce rapid (within 1-4 hr) activation of microglia which is most prominent adjacent to neurons that were destined to die $(36,39)$. At 6-24 $\mathrm{hr}$ after the onset of ischemia, we found here that virtually all activated microglial cells were in 


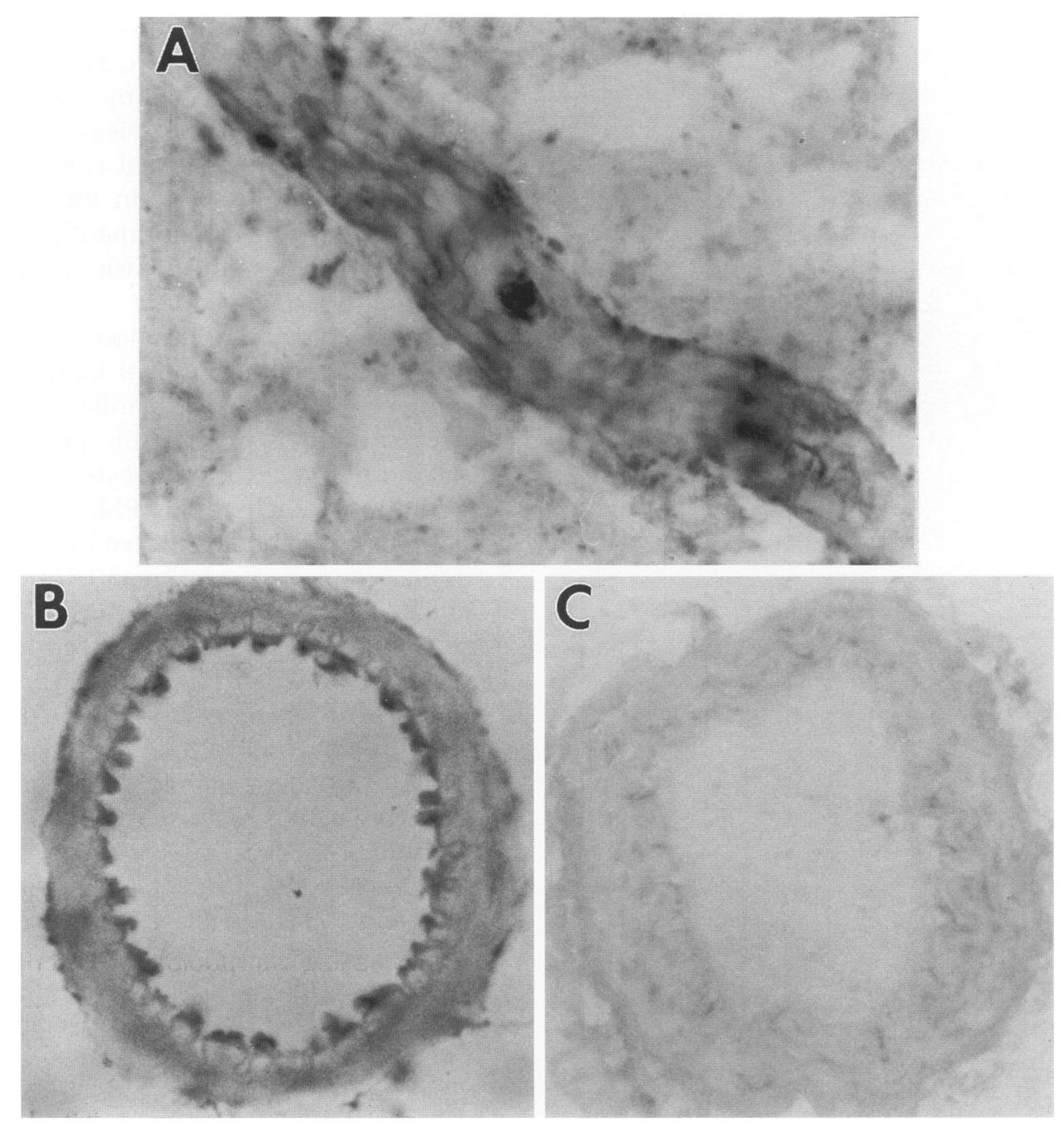

FIG. 5. TNF IR at the surface of a brain vessel (A) and within the endothelium of a transacted vessel (B) No such TNF IR was detected within brain vessels from control animals (C).

close proximity to TNF-expressing neurons. Moreover, we have found a straight correlation between TNF expression and apoptosis within particular neurons at $24 \mathrm{hr}$ after the MCA occlusion: only TUNEL-positive apoptotic neurons expressed TNF IR. These findings are in agreement with the classical viewpoint that neurodegenerative events can signal resting microglia, transforming them into an active form. Although no direct TNF toxicity on neurons was shown $(2,9,40,41)$, there are several observations that TNF can act selectively, destroying diseased cells or those treated with protein synthesis inhibitors $(42,43)$, with little effect on normal cells (ref. from 44). Thus, as TNF increases during ischemia, brain damage increases $(9,10)$.
In response to focal ischemia, some cells displayed a patchy distribution of TNF IR restricted to the cell margin. The multifunctional activities of TNF are thought to be mediated through two molecular forms-a $17-\mathrm{kD}$ mature form and a transmembrane $26-\mathrm{kD}$ precursor protein. TNF IR observed at the periphery of cells may represent this transmembrane form of TNF. TNF signaling via the $26-\mathrm{kD}$ transmembrane form has been associated with contact-dependent lymphocyte and monocyte-mediated cell killing (45), polyclonal B cell activation (46), and localized tissue toxicity (47).

We found that permanent MCA occlusion induced expression of TNF IR in hypertrophic astrocytes within the ischemic penumbra. This 

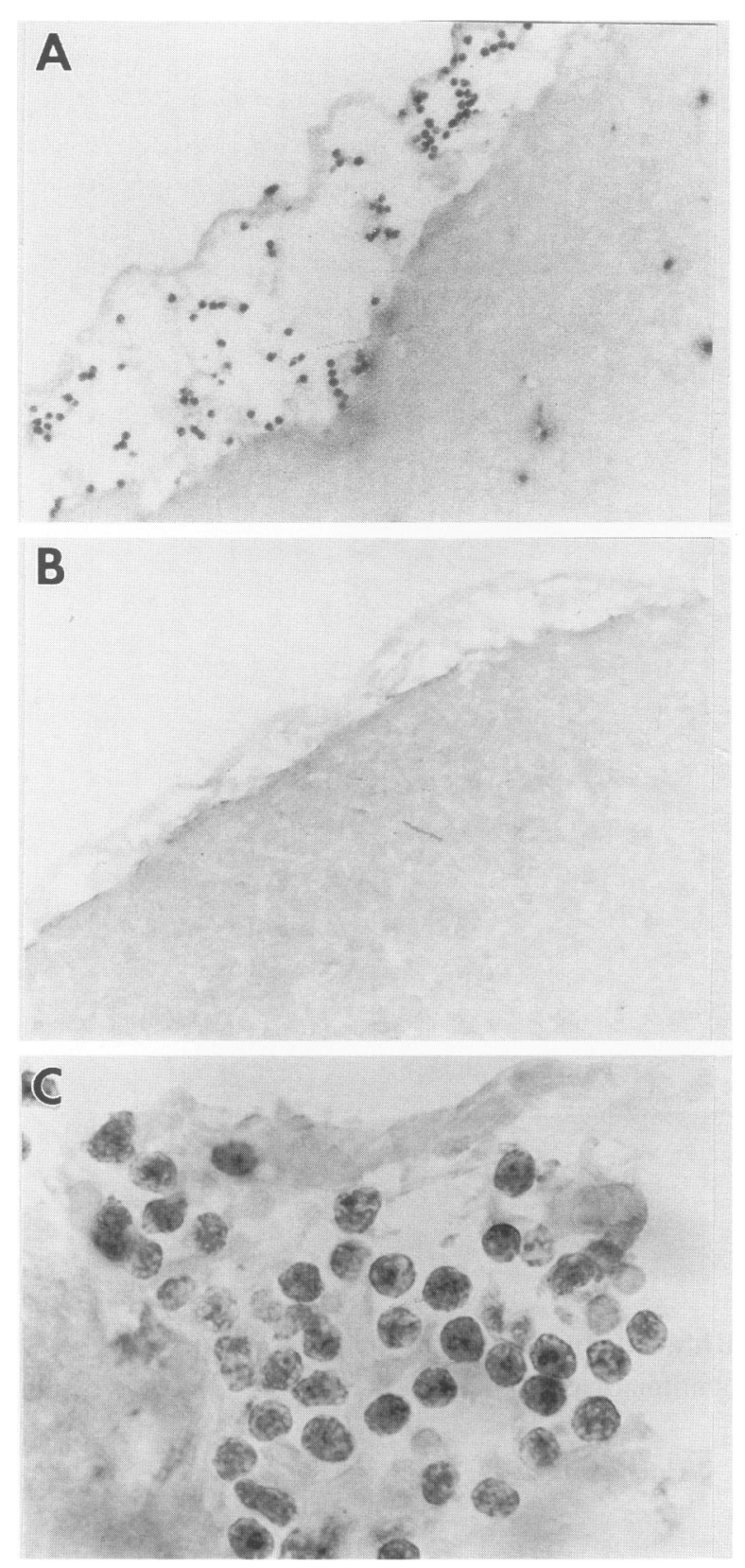

FIG. 6. Expression of TNF by polymorphonuclear leukocytes infiltrating the subarachnoid space and ischemic cortex by $24 \mathrm{hr}$ after permanent MCA occlusion

Low magnification (A); high magnification (C); no PMNs were detected on the contralateral side (B).

observation is in agreement with other experiments using cultured astrocytes. For instance, TNF mRNA expression is markedly elevated in response to exogenous lipopolysaccharide (LPS) (20). Furthermore, the TNF produced by LPSstimulated astrocyte cultures has been shown to be cytotoxic for oligodendrocytes (48). It has also been reported that reactive astrocytes from the brains of patients with multiple sclerosis are positive for TNF IR (49). Our visualization of dense, patchy TNF IR at neuronal cell margins might represent either TNF within the end-feet of reactive astrocytes which intimately surround neuronal cell bodies, or neuron-associated transmembrane TNF, or both.

The leukocyte infiltration that we observed by $24 \mathrm{hr}$ after the onset of ischemia is a wellknown hallmark of CNS inflammation. In the case of brain ischemia, this process is led by polymorphonuclear leukocytes. Infiltration of the brain parenchyma by PMNs from the circulation has been demonstrated in several different animal models of stroke $(50,51)$, and specific adhesion molecules (e.g., ICAM-1, ICAM-2, and ELAM-1) responsible for leucocyte infiltration have been defined. The significance of this inflammatory response in ischemic injury has recently been demonstrated (52-54) since monoclonal antibodies against ICAM-1 significantly reduce ischemic brain damage. In vitro, PMNs cultured from blood can produce TNF mRNA and protein (55). Our results have demonstrated that infiltrating PMN leukocytes strongly expressed TNF IR within ischemic brain tissue. The early appearance of TNF expression (near maximal level by about $6 \mathrm{hr}$ after MCA occlusion; ref. 2 and our results) versus the later appearance of recruited leukocytes suggests that locally produced TNF occurs prior to PMN infiltration. The reinforcement of TNF expression by strongly TNF-expressing infiltrating PMNs might then further contribute to brain damage in stroke. This suggestion is in agreement with the recent demonstration that depletion of leukocytes provides protection against ischemic brain damage $(56,57)$, although other locally produced cytotoxins undoubtedly play a role.

After MCA occlusion, TNF IR was apparent both perivascularly as well as within endothelial cells associated with brain vasculature. Although we can not exclude the possibility that perivascular TNF IR might be partially contributed by pericytes, it seems likely that perivascular TNF is present in astroglial end-feet, which are similarly distributed to surround capillaries but not larger vessels.

The present studies showed that permanent MCA occlusion induced marked up-regulation of p55 and p75 TNF receptor protein expression within ischemic cortex, but with different kinetics and distinct cellular distributions. p55-associ- 

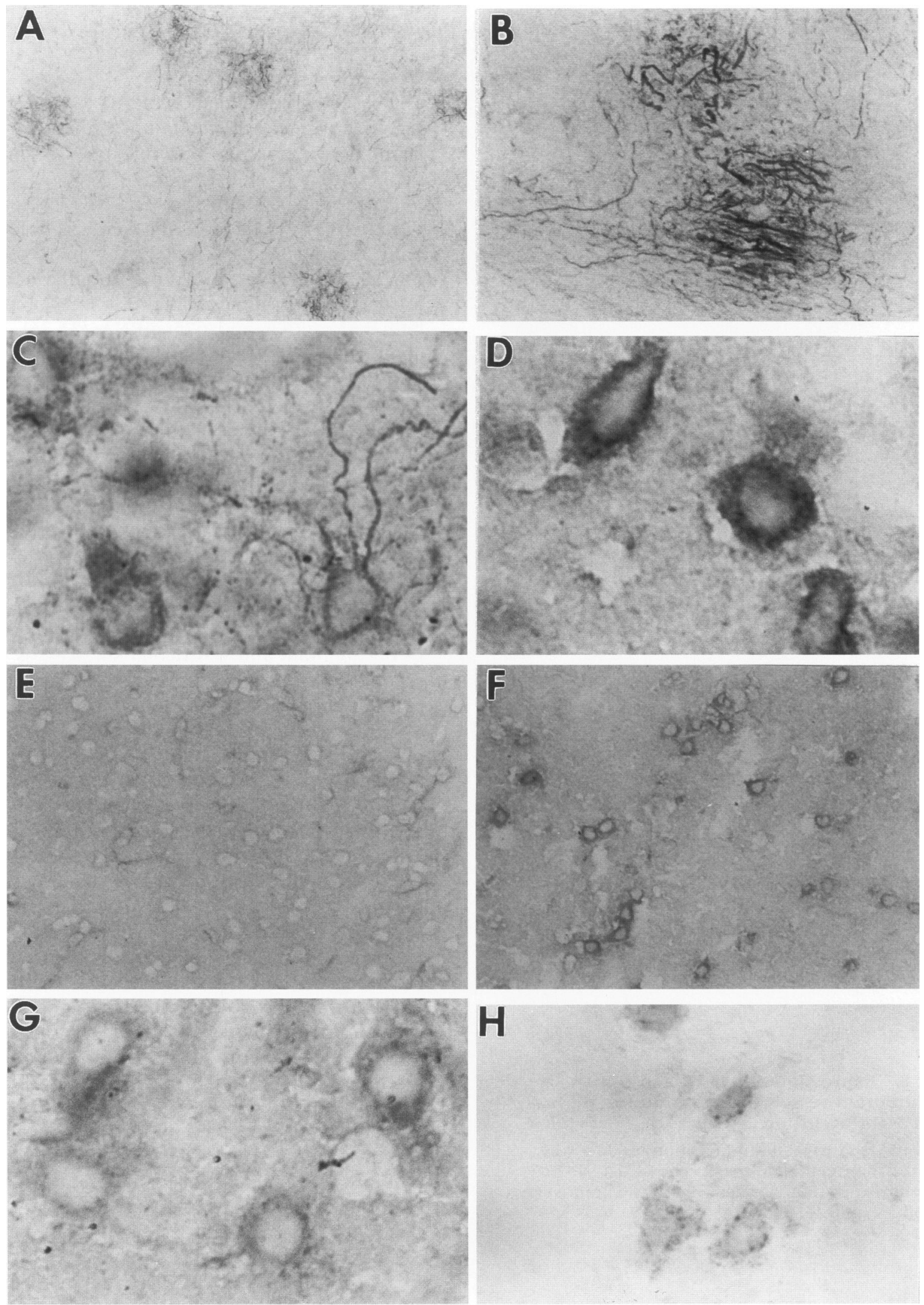

FIG. 7. Expression of $\mathbf{p 5 5}$ and p75 TNF receptors within the ischemic cortex

Permanent MCA occlusion induced a significant increase in the number of "nodules" with dense, fibrillar p55 IR (A, low magnification; B, high magnification). In addition to this pattern, prominent punctate and filamentous p55 IR were detected within the ischemic core and penumbra, as well as a moderate degree of diffuse expression within cell somas (C). By $24 \mathrm{hr}$ after the onset of ischemia, cellular expression of p55 IR was significantly increased (D), and p75 IR became apparent at a detectable level (F, low magnification photomicrograph shows p75 IR within ischemic cortex at $24 \mathrm{hr}$ after the MCA occlusions; G, high magnification). No p75 IR was observed within the contralateral cortex (E). Many cells within the ischemic cortex revealed p75-immunoreactive granules (H). 


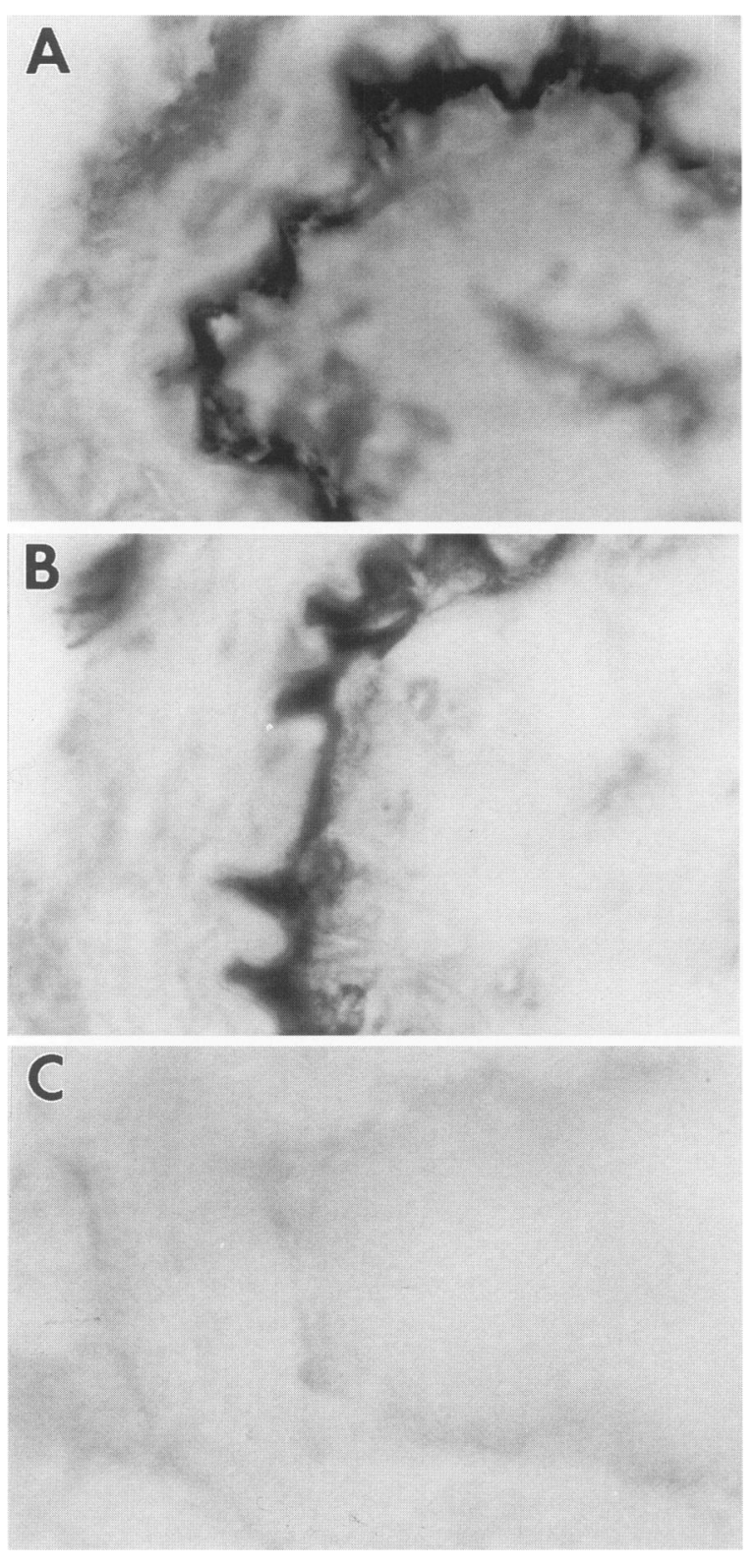

FIG. 8. Expression of p55 IR and p75 IR within brain vessels ipsilateral to the permanent MCA occlusion

Both p55 and p75-immunoreaction product was localized between endothelial cells (A, B). No TNF receptor expression was detected in the brain vessels of control animals (C).

ated IR, for instance, was significantly up-regulated by $6 \mathrm{hr}$ after the onset of ischemia, whereas increased p75 IR was not observed until $24 \mathrm{hr}$. Overall, p55 IR was significantly more abundant than p75 IR during brain ischemia. There is a large body of evidence indicating that TNF cytotoxicity is mediated largely or entirely by $\mathrm{p} 55$.
The observed up-regulation of this TNF receptor, together with the dramatic up-regulation of its ligand, favor an injurious role of TNF during stroke (10).

Although most cells express TNF receptors in vitro, expression of the TNFR genes is differentially regulated in different tissues in vivo (see ref. 26). It has been shown recently that normal astrocytes and glioblastoma cell lines express both p55 mRNA and p75 mRNA $(31,36)$. The absence of p55 IR and p75 IR within GFAPpositive cell bodies ipsilateral to the induced stroke has several possible explanations: (a) a lack of TNF receptor expression by astrocytes during ischemia; $(b)$ a low level of expression that was undetected by double immunofluorescence; and $(c)$ subcellular distribution of receptor proteins via astrocytic processes to the end-feet regions. A combination of the latter two explanations seems consistent with the lack of GFAP/ TNFR double-positive cell bodies despite prominent colocalization of p55 and p75 IR with GFAP IR on the brain and ventricular surfaces, as well as on the cortical capillaries, where astrocytic end-feet form an enveloping layer.

The appearance of both TNF receptors on the inner surface of brain vessel as well as abundunt punctate p55 IR and, to a lesser extent, p75 IR product within ischemic cortex after MCA occlusion might also reflect the extensive induction of soluble TNF receptors. This suggestion is in agreement with data showing that soluble receptors for TNF are highly inducible and can prevent the adverse pathologic sequelae caused by the high level of TNF production in lethal sepsis (59), trauma $(60)$, and stroke $(9,11,12)$. TNFRs are also constitutively shed in substantial amounts in vivo, thus plausibly regulating TNF activity (61). The granule- and dot-like p55 and p75 immunoreactivity we observed during stroke may be the result of increased TNF receptor shedding. The appearance of p55 and p75 immunoreactive granules on the cell surface might reflect not only the up-regulation of membrane-associated receptor expression in response to the MCA occlusion but also receptor aggregation in response to ligand binding (62).

The biological role of TNF in cerebral ischemia is probably dependent upon a balance in signaling via both p55 and p75, but it is not yet clear what the consequences of these molecular interactions will be for the ischemic brain. It has been reported in cultured neuronal cells that TNF can be either neurotrophic or neurotoxic, depending on unidentified factors in the culture 

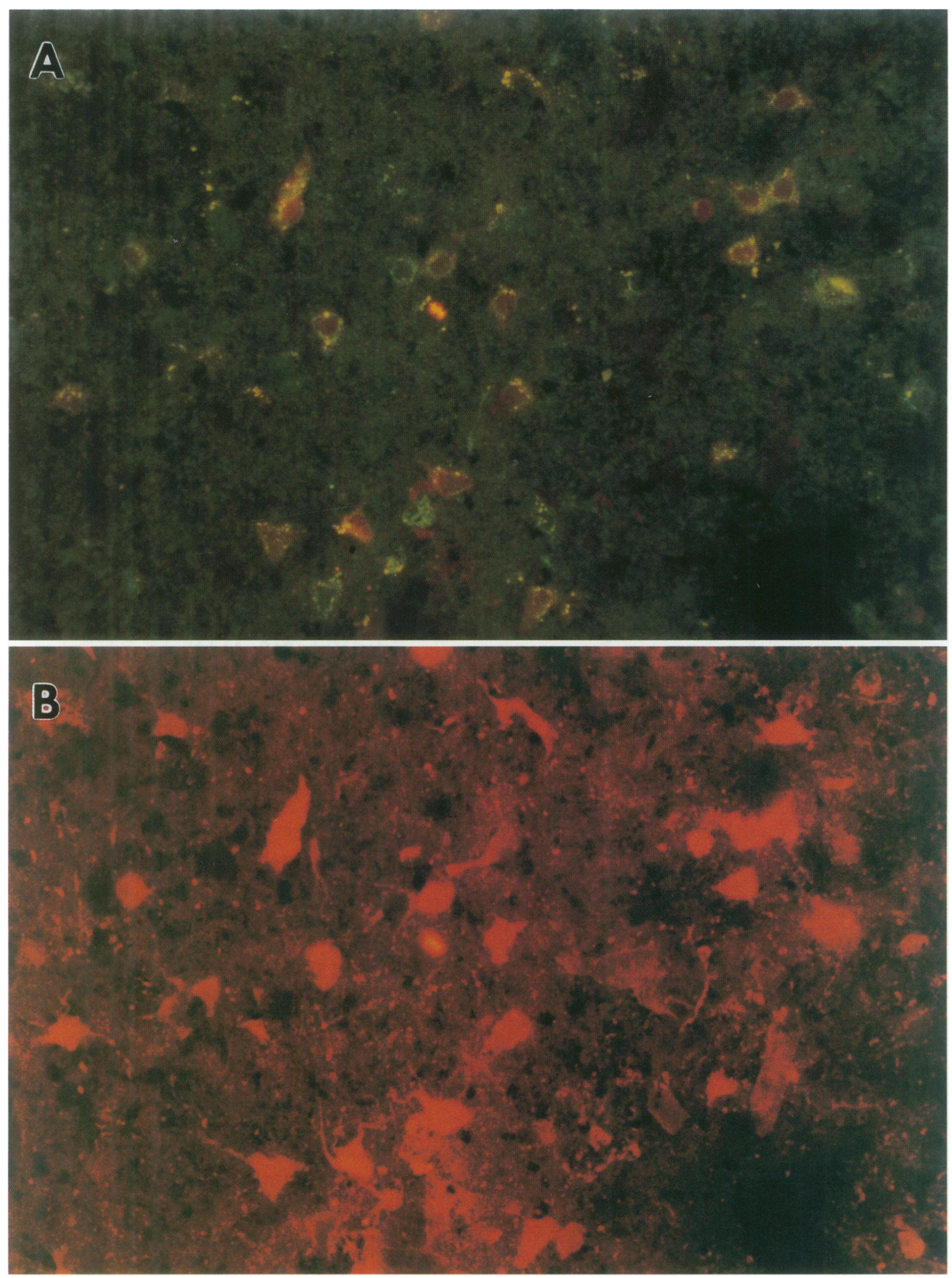

FIG. 9. Triple staining (double-fluorescent immunohistochemistry for TNF and NF200 plus TUNEL staining for detection of apoptotic cell death) in ischemic cortex at $24 \mathrm{hr}$ after the MCA occlusion

This triple staining showed that only neurons exhibiting apoptotic changes express TNF IR. Double exposure (A) of green fluorescence for NF200 and bright-field microscopy for TUNEL staining (brown nuclei) resulted in yellowish cytoplasm in TUNEL-positive neurons; alive neurons had green cytoplasm. Only neurons that were TUNELpositive expressed TNF IR (B, red filter). 
conditions $(63,64)$. Some authors have found no direct TNF toxicity on neurons $(2,9,40,41)$, but other observations suggest that TNF can act selectively, destroying diseased or otherwise stressed cells $(42,43)$, while having no effect on normal cells (44). Our results clearly show strongly induced TNF expression by $6 \mathrm{hr}$ after permanent MCA occlusion, preceding the period of extensive brain cell death. It is likely therefore that TNF mediates cellular damage and toxicity in stroke. This suggestion is supported by recent evidence showing the neuroprotective effects of TNF inhibition in experimental ischemia by administrating neutralizing anti-TNF antibodies, or a tetravalent guanylhydrazone inhibitor of TNF synthesis (CNI-1493), either of which significantly reduce infarct volume (10). Inhibition of TNF protects against the development of cerebral edema $(9,65)$ and soluble TNFR 1 administration is neuroprotective $(9,11,12)$. It now appears that the enhanced production of TNF and its receptors on glial, neuronal and peripheral inflammatory cells occupies a pivotal role in mediating the injurious effects of brain ischemia.

\section{REFERENCES}

1. Buttini M, Appel K, Sauter A, GebickeHaerter P-J, Boddeke H. (1996) Expression of tumor necrosis factor alpha after focal cerebral ischemia in the rat. Neuroscience 71: 1-16.

2. Liu T, Clark RK, McDonnell PC, Young PR, White RF, Barone FC, Feuerstein GZ. (1994) Tumor necrosis factor- $\alpha$ expression in ischemic neurons. Stroke 25: 1481-1488.

3. Taupin V, Toulmond S, Serrano A, Benavides J, Zavala F. (1993) Increase in IL-6, IL-1 and TNF levels in rat brain following traumatic lesions. J. Neuroimmunol. 42: 177186.

4. Woodroofe MN, Sarna GS, Wadhwa M, et al. (1991) Detection of interleukin-1 and interleukin-6 in adult rat brain following mechanical injury, by in vivo microdialysis: Evidence of a role for microglia in cytokine production. J. Neuroimmunol. 33: 227-236.

5. Tchelingerian J-L, Quinonero J, Booss J, Jacque C. (1993) Localization of TNF- $\alpha$ and IL-1 immunoreactivities in striatal neurons after surgical injury to hippocampus. Neuron. 10: 213-224.

6. Fan L, Young PR, Barone FC, Feuerstein GZ, Smith DH, McIntosh TK. (1996) Experimen- tal brain injury induces differential expression of tumor necrosis factor-mRNA in the CNS. Mol. Brain Res. 36: 287-291.

7. Szaflarski J, Burtrum D, Silverstein FS. (1995) Cerebral hypoxia-ischemia stimulates cytokine gene expression in perinatal rats. Stroke 26: 1093-1100.

8. Tracey KJ, Vlassara H, Cerami A. (1989) Cachectin/tumour necrosis factor. Lancet I: 1122-1126.

9. Barone FC, Arvin B, White RF, Miller A, Webb CL, Willette RN, Lysko PG, Feuerstein GZ. (1997) Tumor necrosis factor- $\alpha$. A mediator of focal ischemic brain injury. Stroke 28: 1233-1244.

10. Meistrell III ME, Botchkina GI, Wang H, DeSanto E, Cockroft KM, Bloom O, Vishnubhakat JM, Ghezzi P, Tracey KJ. (1997) TNF is a brain-damaging cytokine in cerebral ischemia. Shock In press.

11. Dawson DA, Martin D, Hallenbeck JM. (1996) Inhibition of tumor necrosis factoralpha reduces focal cerebral ischemic injury in the spontaneously hypertensive rat. $\mathrm{Neu}$ rosci. Lett. 218: 41-44.

12. Navashiro $H$, Martin $D$, Hallenbeck JM. (1997) Inhibition of tumor necrosis factor and amelioration of brain infarction in mice. J. Cereb. Blood Flow Metab. 17: 229-232.

13. Bruce AJ, Boling W, Kindy MS, Peschon J, Kraemer PJ, Carpenter MK, Holtsbert FW, Mattson MP. (1996) Altered neuronal and microglial responses to excitotoxic and ischemic brain injury in mice lacking TNF receptors. Nature Med. 2: 788-794.

14. Aggarwal BB. (1992) Comparative analysis of the structure and function of TNF- $\alpha$ and TNF- $\beta$. Immunol. Ser. 56: 61-78.

15. Turetskaya RL, Fashena SJ, Paul NL, Ruddle NH. (1992) Genomic structure, induction, and production of TNF- $\alpha$. Immunol. Ser. 56: 35-60.

16. Frei K, Siepl C, Groscurth P, Bodmer S, Schwerdel C, Fontana A. (1987) Antigen presentation and tumor cytotoxicity by interferon- $\gamma$-treated microglial cells. Eur. J. Immunol. 17: 1271-1278.

17. Sawada $M$, Kondo N, Suzumura A, Marunouchi T. (1989) Production of TNF- $\alpha$ by microglia and astrocytes in culture. Brain Res. 491: 394-397.

18. Lieberman AP, Pitha PM, Shin HS, Shin ML. (1989) Production of tumor necrosis factor and other cytokines by astrocytes stimulated with lipopolysaccharide or a neurotropic vi- 
rus. Proc. Natl. Acad. Sci. U.S.A. 86: 63486352.

19. Chung IY, Benveniste EN. (1990) Tumor necrosis factor alpha production by astrocytes. Induction by lipopolysaccharide, interferon gamma and interleukin 1 beta. J. Immunol. 144: 2999-3007.

20. Wesselingh SL, Gough NM, Finlay-Jones JJ, McDonald PJ. (1990) Detection of cytokine mRNA in astrocyte culture using the polymerase chain reaction. Lymphokine Res. 9: 177-185.

21. Tarlow MJ, Jenkins R, Comist SD, Osborne MP, Stephens S, Stanley P, Crokers J. (1993) Ependymal cells of the choroid plexus express tumour necrosis factor- $\alpha$. Neuropathol. Appl. Neurobiol. 19: 324-328.

22. Beutler B. (1992) Tumor Necrosis Factors: The Molecules and Their Emerging Role in Medicine. New York, Raven Press.

23. Tartaglia LA, Goeddel DV. (1992) Two TNF receptors. Immunol. Today 13: 151-153.

24. Rothe J, Gehr G, Loetscher H, Lesslauer W. (1992) Tumor necrosis factor receptorsstructure and function. Immunol. Res. 11: 8190.

25. Pfizenmaier $K$, Himmler A, Schutze $S$, Scheurich P, Kronke M. (1992) TNF receptors and TNF signal transduction. Beutler $B$ (ed). In Tumor Necrosis Factors: The molecules and their emerging role in medicine. Raven Press, New York, pp. 439-472.

26. Vandenabeele $P$, Declercq $W$, Beyaert $R$, Fiers W (1995) Two tumor necrosis factor receptors: structure and function. Trends Cell Biol. 5: 392-399.

27. Smith CA, Farrah T, Goodwin RG. (1994) The TNF receptor superfamily of cellular and viral proteins: Activation, costimulation and death. Cell 76: 959-962.

28. Tartaglia LA, Weber RF, Figari IS, Reynolds C, Pallachino MA, Jr, Goeddell DV. (1991) The two different receptors for tumor necrosis factor mediate distinct cellular responses. Proc. Natl. Acad. Sci. U.S.A. 88: 9292-9295.

29. Tartaglia LA, Goeddell DV, Reynolds C, Figari IS, Weber RF, Fendly BM, Palladino MA. (1993) Stimulation of human T-cell proliferation by specific activation of the 75-kD tumor necrosis factor receptor. $\mathrm{J}$. Immunol. 151: 4637-4641.

30. Grell M, Scheurich P, Meager A, Pfizenmaier K. (1993) TR60 and TR80 tumor necrosis factor (TNF)-receptors can independently mediate cytolysis. Lymphokine and Cytokine Res. 12, Nov. 3: 143-148.

31. Tada M, Diserens A-C, Desbaillets I, et al. (1994) Analysis of cytokine receptor messenger RNA expression in human glioblastoma cells and normal astrocytes by reverse transcription polymerase chain reaction. J. Neurosurg. 80: 1063-1073.

32. Shen Y, Li R, Shiosaki K. (1997) Inhibition of p75 tumor necrosis factor receptor by antisense oligonucleotides increases hypoxic injury and beta-amyloid toxicity in a human neuronal cell line. J. Biol. Chem. 272: 35503553.

33. Zimmerman GA, Meistrell M III, Bloom O, Cockroft KM, Bianchi M, Risucci D, Broom J, Farmer P, Cerami A, Vlassara $\mathrm{H}$, et al. (1995) Neurotoxicity of advanced glycation endproducts (AGEs) during focal stroke, and neuroprotective effects of aminoguanidine. Proc. Natl. Acad. Sci. U.S.A. 92: 3744-3748.

34. Cockroft KM, Meistrell M III, Zimmerman GA, Risucci D, Bloom O, Cerami A, Tracey KJ. (1996) Cerebroprotective effects of aminoguanidine in a rodent model of stroke. Stroke 27: 1393-1398.

35. Breder CD, Tsujimoto $M$, Terano $Y$, Scott DW, Saper CB. (1993) Distribution and caracterization of tumor necrosis factor- $\alpha$-like immunoreactivity in the murinecentral nervous system. J. Comp. Neurol. 337: 543-567.

36. Kato HK, Kogure T, Araki T, Itoyoma Y. (1994) Astroglial and microglial responses in the gerbil hippocampus with induced ischemic intolerance. Brain Res. 664: 69-76.

37. Korematsu K, Goto S, Nagahiro S, Ushio Y. (1994) Microglial response to transient focal ischemia: An immunocytochemical study on the rat cerebral cortex using anti-phosphotyrosine antibody. J. Cereb. Blood Flow Metab. 14: 825-830.

38. Nishino H, Czurko A, Fukuda A, Hashitani T, Hida H, Karadi Z, Lenard L. (1994) Pathophysiological processes after transient ischemia of the middle cerebral artery in the rat. Brain Res. Bull. 35: 51-56.

39. Zimmer LA, Ennis M, Shipley MT. (1997) Soman-induced seizures rapidly activate astrocytes and microglia discrete brain regions. J. Comp. Neurol. 378: 482-492.

40. Garcia JE, Nonner D, Ross D, Barrett JN. (1992) Neurotoxic components in normal serum. Exp. Neurol. 118: 309-316.

41. Piani D, Spangler M, Schaffner A, Montana A. (1992) Macrophage-induced cytoxicity of 
$N$-methyl-D-aspartate receptor positive neurons involves excitatory amino acids rather than reactive oxygen intermediates and cytokines. Eur. J. Immunol. 22: 2429-2436.

42. Hahn T, Toker L, Budilovsky S, Aderka D, Eahhar Z, Wallach D. (1985) Use of monoclonal antibodies to a human cytotoxin for its isolation and for examining the self-induction of resistance to this protein. Proc. Natl. Acad. Sci. U.S.A. 82: 3814-3818.

43. Nophar Y, Holtmann H, Ber R, Wallach D. (1988) Dominance of resistance to the cytocidal effect of tumor necrosis factor in heterokarions by fusion of resistant and sensitive cells. J. Immunol. 140: 3456-3460.

44. Wallach D. (1997) Cell death induction by TNF: A matter of self control. Trends Biochem. Sci. 22: 107-109.

45. Peck R, Brockhaus M, Frey JR. (1989) Cell surface tumor necrosis factor (TNF) accounts for monocyte- and lymphocyte-mediated killing of TNF-resistant target cells. Cell Immunol. 122: 1-10.

46. Macchia D, Almeriogna F, Parronchi P, Ravina A, Maggi E, Romagnani S. (1993) Membrane tumor necrosis factor is involved in the polyclonal B-cell activation induced by HIV infected human T-cells. Nature 363: 464-466.

47. Georgopulos S, Plows D, Kollias G. (1996) Transmembrane TNF is sufficient to induce localized tissue toxicity and chronic inflammatory arthritis in transgenic mice. J. Inflammation 46: 86-87.

48. Robbins DS, Shirazi Y, Drysdale B-E, Lieberman A, Shin HS, Shin ML. (1987) Production of cytotoxic factor from oligodentrocytes by stimulated astrocytes. J. Immunol. 139: 2593-2597.

49. Hofman FM, Hinton DR, Johnson K, Merill JE. (1989) Tumor necrosis factor identified in multiple sclerosis brain. J. Exp. Med. 170: 607-612.

50. Arvin B, Neville LF, Barone FC, Feuerstein GK. (1995) Brain injury and inflammation. A putative role of TNF alpha. Ann. N.Y. Acad. Sci. 765: 62-99.

51. Wang XK, Yue T-L, Young PR, Barone FR, Feuerstein GZ. (1995) Expression of interleukin-6, c-fos, and zif268 mRNAs in rat ischemic cortex. J. Cereb. Blood Flow Metab. 15: $166-171$.

52. Clark WM, Madden KP, Rothlein R, Zivin JA. (1991) Reduction of central nervous system ischemic injury by monoclonal antibody to intercellular adhesion molecule. J. Neurosurg. 75: 623-627.

53. Bowles WP, Zivin JA, Rothlein R. (1993) Monoclonal antibody to the ICAM-l adhesion site reduces neurological damage in a rabbit cerebral embolism stroke model. Exp. Neurol. 119: 215-219.

54. Zhang RL, Chopp M, Li Y, Zaloga C, Jiang N, Jones M, Miyasaka M, Ward P. (1994) AntiICAM-1 antibody reduces ischemic cell damage after transcient middle cerebral artery occlusion in the rat. Neurology 44: 1747-1751.

55. Dubravec DB, Spriggs DR, Mannick JA, Rodrick ML. (1990) Circulating human peripheral blood granulocytes synthesize and secrete tumor necrosis factor alpha. Proc. Natl. Acad. Sci. U.S.A. 87: 6758-6761.

56. Chen H, Chopp M, Bodzin G. (1992) Neurotropenia reduces the volume of cerebral infarct after transient middle cerebral occlusion in the rat. Neurosci. Res. Commun. 11: 93-99.

57. Shiga $Y$, Onnodera H, Kogere K, Yamasaki $Y$, Yashima Y, Syozuhara H, Sendo F. (1991) Neutrophil as a mediator of ischemic edema formation in the brain. Neurosci. Lett. 125: 110-112.

58. Sippy BD, Hofman FM, Wallach D, Hinton DR. (1995) Increased expression of tumor necrosis factor-receptors in the brain of patients with AIDS. J. AIDS Hum. Retrovirol. 10: 511-521.

59. Van Zee KJ, Kohno T, Fischer E, Rock CS, Moldawer LL, Lowry SF. (1992) Tumor necrosis factor soluble receptors circulate during experimental and clinical inflammation and can protect against excessive tumor necrosis factor alpha in vitro and in vivo. Proc. Natl. Acad. Sci. U.S.A. 89: 4845-4849.

60. Keel $M$, Bonaccio $M$, Steckholder U, Ungethum U, Gallati $\mathrm{H}$, Trentz O, Ertel W. (1995) Increased plasma level of Type 1 (p55) TNF-receptors following trauma. Swiss Surg. 5: 241-244.

61. Pinckard JK, Sheehan KC, Arthur CD, Schreiber. (1997) Constitutive shedding of both p55 and p75 murine TNF receptors in vivo. J. Immunol. 158: 3869-3873.

62. Banner D, D'Arcy A, Janes W, Gentz R, Schoenfeld H-J, Broger C, Loetscher H, Lesslauer W. (1993) Crystal structure of the soluble human $55 \mathrm{kd}$ TNF receptor-human TNFcomplex: Implications for TNF receptor activation. Cell 73: 431-445. 
63. Chao CC, Hu S. (1994) Tumor necrosis factor-alpha potentiates glutamate neurotoxicity in human fetal brain cell cultures. Dev. Neurosci. 16: 172-179.

64. Cheng B, Christakos S, Mattson MP. (1994) Tumor necrosis factors protect neurons against excitotoxic metabolic insults and promote maintenance of calcium homeostasis. Neuron 12: 139-153.

65. Shohami E, Bass R, Wallach D, Yamin A, Gallily R. (1996) Inhibition of tumor necrosis factor alpha activity in rat brain is associated with cerebroprotection after closed head injury. J. Cereb. Blood Flow Metab. 16: 378-384.

Communicated by F. Bloom. Accepted September 24, 1997. 